\title{
A review of data visualisation: opportunities in manufacturing sequence management
}

\section{P. J. SACKETT $\dagger$, M. F. AL-GAYLANI $\dagger$, A. TIWARI*† and D. WILLIAMS§}

†Enterprise Integration, Cranfield University, Cranfield, Bedfordshire, MK43 0AL, UK.

Tel: +44 (0) 1234 754073, Fax: +44 (0) 1234750852

Email: \{p.j.sackett, mohammedfalih, a.tiwari\}@cranfield.ac.uk

§dave.williams@digitalquay.co.uk

*Corresponding author. Email: a.tiwari@cranfield.ac.uk

Data visualisation now benefits from developments in technologies that offer innovative ways of presenting complex data. Potentially these have widespread application in communicating the complex information domains typical of manufacturing sequence management environments for global enterprises. In this paper the authors review the visualisation functionalities, techniques and applications reported in literature, map these to manufacturing sequence information presentation requirements, and identify the opportunities available and likely development paths. Current leading edge practice in dynamic updating and communication with suppliers is not being exploited in manufacturing sequence management; it could provide significant benefits to manufacturing business. In the context of global manufacturing operations and broad based user communities with differing needs served by common data sets, tool functionality is generally ahead of user application.

Keywords: Manufacturing Sequence; Data Visualisation; Global Manufacturing

\section{Article Type: Review Article}

\section{Introduction}

Aristotle concluded that thought is impossible without an image. Thomas Babington Macaulay noted that '... logicians may reason about abstractions. But the great mass of men must have images'.

Visualisation is "the process of representing data as a visual image" (Latham 1995). It is a longstanding foundation tool for human understanding. Graphical representations can communicate complex information, help understand complicated relationships between multiple variables, uncover information hidden in the data, and solve problems through visual representations in the form of data structures for expressing knowledge. Data Visualisation embraces digital images, geographical information systems, graphical user interfaces, multidimensional tables and graphs, three-dimensional animation and virtual reality.

Visual representations can facilitate problem-solving and discovery by providing a structure for expressing and communicating meaning of highly abstract data. Visualisation potentially allows decision makers to exploit their natural spatial/visual abilities. This implies that visualisation, used appropriately, can allow the decision maker to find the information in the data; it is a process for transforming data into forms that allow diverse users to comprehend and interact with the information more effectively. In the limit this can take the form of a man-machine interface for the virtual presentation and manipulation of 3-D data in real time. Any visual representation that augments understanding of raw data is part of an information reality environment, Figure 1. 


\section{P. J. Sackett et al.}

Figure 1: Features of information reality (adapted from Wiendahl and Fiebig (2003))

The field of manufacturing scheduling theory and practice is well researched and extensively applied. Manufacturing sequencing is the control of orders within the manufacturing process facility to provide a sequence of orders that cost effectively satisfies the sequence broadcast to the supply chain and the demands of end customers. It is a classic complex problem domain that has the potential to defeat many analytical techniques in all but the simplest application. In manufacturing sequence management control applications such as responsive mode mixed model production lines, the demands on the decision makers to rapidly interpret complex data and formulate a corrective response are challenging. It would seem that the exploitation of data visualisation would be highly appropriate. However, a recent review concluded that there is little published information on the application of visualisation to manufacturing sequence management (Sackett and Williams 2003a). This problem domain is increasing in complexity with the adoption of Lean Manufacturing and the Globalisation of supply chains with resultant high impact and rapid up and down chain interactions. Manufacturing sequencing has been a long term issue for automotive manufacturers but the context now extends across many product sectors such as white goods and electronics.

In this paper the authors review the techniques available, map these to manufacturing sequence information presentation requirements and identify the opportunities available and likely development paths.

\section{Visual representations}

The importance of visual representation to support decision making has been emphasised by many researchers (Tufte 1990, Foil and Huff 1992, Morgan 1993, Lohse et al. 1994, Eden and Ackerman 1998, Rohrer 2000, Gausemeier et al. 2001, Tan and Platts 2003b). Visualisation is an accessible form of knowledge representation (Larkin and Simon 1987). Managers perform better when their problem-solving processes are adapted to the problem representation (Vessey 1991). Mckim (1972) sees visualisation as a "visual" vehicle of thought to assist managers in making decisions. Foil and Huff (1992) point out that visual representation provides new ways of examining and improving managerial judgement. Visual representations are a means of displaying graphically the firm's current strategic position, identifying alternative routes to improving that position.

Cognitive Fit Theory states that a solution to a problem is "an outcome of the relationship between the problem representation and problem solving tasks" (Vessey 1991). The better the "fit" is between these two constructs, the more effective and efficient the problem solving process. Therefore, when developing information visualisations, the developer must pay attention to the tasks performed by the decision-maker if the visualisation is to be useful.

The manufacturing sequence problem solving tasks that visualisation technology can address are: exploratory, confirmatory, and production (Grinstein and Ward 2002).

- Exploratory tasks tend to be dynamic. Users are normally attempting to search for structure or trends that can be gleaned from the visualisation or create/test hypotheses about the underlying information.

- Confirmatory tasks tend to be stable and predictable. The users normally attempt to confirm or refute hypotheses. 
- Production-based tasks are reporting related. The users already have a validated hypothesis and are using a visualisation-based report.

Table 1 shows the offered functions of visualisation, corresponding to the three manufacturing sequence problem solving tasks outlined above.

Table 1: Visualisation functionalities (adapted from Platts and Kim (2004))

\section{Techniques and designs}

Information visualisation processes and tools are determined by the data type, the technique, and the interaction and distortion used, Figure 2 (Keim 2001).

Figure 2: Classification of information visualisation techniques (adapted from Keim (2001))

The data type is set by the system to be visualised. As discussed below, it can range through onedimensional, two-dimensional, multi-dimensional, text/web, hierarchies/graphs, and algorithm/software:

- One-dimensional Data: Usually has one dense dimension. A typical example is temporal data as used in ThemeRiver (Nowell et al. 2002).

- Two-dimensional Data: Has two distinct dimensions. A typical example is geographical data. X-Y-plots are a typical method for showing two-dimensional data and maps are a special type of X-Y-plots for showing two dimensional geographical data. Examples are the geographical maps used in Polaris (Tang et al. 2002).

- Multidimensional Data: Data sets consisting of more than three attributes. Examples are tables from relational databases, which often have tens to hundreds of columns (or attributes). An example of a technique which allows the visualisation of multidimensional data is the Parallel Coordinate Technique (Inselberg and Dimsdale 1990). Parallel Coordinates display each multidimensional data item as a polygonal line which intersects the horizontal dimension axes at the position corresponding to the data value for the corresponding dimension.

- Text and Hypertext: Cannot be easily described by numbers, and therefore most of the standard visualisation techniques cannot be applied. In most cases, a transformation of the data into description vectors is necessary first before visualisation techniques can be used. An example for a simple transformation is word counting (see ThemeRiver in Nowell et al. (2002)), which is often combined with a principal component analysis or multidimensional scaling (Wise et al. 1995).

- Hierarchies and Graphs: Data records having relationship to other pieces of information. Graphs are widely used to represent such interdependencies. Examples are the e-mail interrelationships among people, their shopping behaviour, the file structure of the hard disk, or the hyperlinks in the world wide web. An overview of hierarchical information visualisation techniques can be found in Chen (1999), and an overview of web visualisation techniques in Dodge (2001).

- Algorithms and Software: Support software development by helping to understand algorithms, e.g., by showing the flow of information in a program to enhance the understanding of written code. This can be 


\section{P. J. Sackett et al.}

achieved by representing the structure of thousands of source code lines as graphs to support the programmer in debugging the code as used in Polaris (Tang et al. 2002) by visualising errors.

The display techniques can range through:

- Standard 2D/3D Displays: Such as bar charts and x-y plots (Tang et al. 2002).

- Geometrically Transformed Displays: Aimed at finding "interesting” transformations of multidimensional data sets. The class of geometric display techniques includes techniques from exploratory statistics, such as scatterplot matrices (Cleveland 1993) and techniques which can be subsumed under the term "projection pursuit" (Huber 1985). Other geometric projection techniques include Prosection Views (Spence et al. 1995), Hyperslice (van Wijk and van Liere 1993), and the well-known Parallel Coordinates visualisation technique (Inselberg and Dimsdale 1990).

- Iconic Displays: Used to map the attribute values of a multidimensional data item to the features of an icon. Icons may be little faces (Chernoff 1973), needle icons as used in MultidiGraph Visualisation (MGV) (Abello and Korn 2002), star icons (Ward 1994), stick figure icons (Pickett and Grinstein 1988), colour icons (Levkowitz 1991, Keim and Kriegel 1994), and TileBars (Hearst 1995). Examples of needle icons, star icons, and stick figure icons are presented in Figures 3, 4 and 5 respectively. The visualisation is generated by mapping the attribute values of each data record to the features of the icons.

- Dense Pixel Displays: Mapping of each dimension value to a coloured pixel and grouping of the pixels belonging to each dimension into adjacent areas (Keim 2000). Since, in general, dense pixel displays use one pixel per data value, the techniques allow the visualisation of the largest amount of data possible on current displays (up to about 1,000,000 data values). Dense pixel techniques use different arrangements for different purposes. By arranging the pixels in an appropriate way, the resulting visualisation provides detailed information on local correlations, dependencies, and hot spots. A well-known example is the recursive pattern technique (Keim et al. 1995). This technique is based on a generic recursive back-andforth arrangement of the pixels and is particularly aimed at representing datasets with a natural order according to one attribute (e.g., time series data). The user may specify parameters for each recursion level and thereby control the arrangement of the pixels to form semantically meaningful substructures.

- Stacked Displays: Are tailored to present data partitioned in a hierarchical fashion. In the case of multidimensional data, the data dimensions to be used for partitioning the data and building the hierarchy have to be selected appropriately. An example of a stacked display technique is Dimensional Stacking (LeBlanc et al. 1990). These embed one coordinate system inside another coordinate system. The display is generated by dividing the outmost level coordinate systems into rectangular cells and, within the cells, the next two attributes are used to span the second level coordinate system. This process may be repeated. A dimensional stacking visualisation of oil mining data with longitude and latitude mapped to the outer $\mathrm{x}$ and $y$ axes, as well as ore grade and depth mapped to the inner $\mathrm{x}$ and $\mathrm{y}$ axes, is shown in Figure 6. Other examples of stacked display techniques include Worlds-within-Worlds (Feiner and Beshers 1990), Treemap (Johnson and Shneiderman 1991, Shneiderman 1992), and Cone Trees (Robertson et al. 1991).

Figure 3: A needle grid view of call data. Each axis represents the states of the US and density of phone calls made between pairs of states is represented with a needle with multiple visual cues: colour, angle, and length (source reference: Abello and Korn (2002))

Figure 4: A star-map view of call data, superimposed with geographic information. For each state, a star is drawn which consists of line segments that represent phone call density to each other state. The circular order of the states is the same for all stars (source reference: Abello and Korn (2002)) 
Figure 5: Stick figure visualisation technique: (a) Stick figure icon, (b) A family of stick figures (source reference: Keim and Kriegel (1994))

Figure 6: Dimensional stacking visualisation of oil mining data (source reference: Keim (2002))

In addition to the visualisation techniques, it is necessary to use some interaction and distortion techniques. Interaction techniques allow the data analyst to directly interact with the visualisations and dynamically change the visualisations according to the exploration objectives. They also make it possible to relate and combine multiple independent visualisations. Distortion techniques show portions of the data with a high level of detail. The interaction and distortion techniques can be classified into:

- Dynamic Projections: Change the projections to explore a multidimensional data set. A classic example is the GrandTour system (Asimov 1985), which tries to show all interesting two-dimensional projections of a multi-dimensional data set as a series of scatter plots.

- Interactive Filtering: Partitions the data set into segments and focus on interesting subsets. An example of a tool which can be used for interactive filtering is Magic Lenses (Bier et al. 1993). Other examples of interactive filtering techniques and tools are InfoCrystal (Spoerri 1993) and Polaris (Tang et al. 2002).

- Interactive Zooming: Data representation automatically changes to present more details on higher zoom levels. An interesting example applying the zooming idea to large tabular data sets is the TableLens approach (Rao and Card 1994).

- Interactive Distortion: Interactive distortion techniques support the data exploration process by preserving an overview of the data during drill-down operations. The basic idea is to show portions of the data with a high level of detail while others are shown with a lower level of detail. It should be noted that there is a clear distinction between diagnosing a problem through the visualisation and identifying the cause of the problem. The drill-down functionality associated with interactive distortion allows the users to focus on causality. Popular distortion techniques are hyperbolic and spherical distortions. Examples of distortion techniques include Bifocal Displays (Spence and Apperley 1982), Perspective Wall (Mackinlay et al. 1991), Graphical Fisheye Views (Sarkar and Brown 1994), Hyperbolic Visualisation (Munzner and Burchard 1995), and Hyperbox (Alpern and Carter 1991).

- Interactive Linking and Brushing: The idea of linking and brushing is to combine different visualisation methods to overcome the shortcomings of a single technique. Typical examples of visualisation techniques which are combined by linking and brushing are multiple scatterplots, bar charts, parallel coordinates, pixel displays, and maps. Most interactive data exploration systems allow some form of linking and brushing. Examples are Polaris (Tang et al. 2002) and the Scalable Framework (Lopez et al. 2002).

\section{Information presentation requirements}

\subsection{Examples of real-life systems for information presentation}

The key challenges for information visualisation include creating visual representations that utilise human visual perceptual capability and enhance human information comprehension. As an example, Andon systems encompass visual display of manufacturing data from simple metrics to more complicated performance or 


\section{P. J. Sackett et al.}

status measures (Phaal et al. 2004). Andon became popular in the late 1980's in Japan and elsewhere as a key component of the Just-In-Time manufacturing philosophy. Traditional Andon systems consist of a panel of lights, each of which are connected to machines and devices located on the factory floor. Whenever the state of a machine or device changes (e.g., in operation, not in operation, jammed, etc.), the Andon panel gives managers an immediate, visual update regarding the change. Unlike traditional Andon systems using light bulbs hard-wired to machines, the new generation Andon systems work through the computer video monitor. The display is user-configurable. The user can add new physical devices at any time and determine the circumstances under which the device should alert managers via the Andon display.

Another example is TreeMaps (Asahi et al. 1995) that is designed to visualise large amounts of hierarchical and categorical information such as file directories, budgets, sales data, and organisational structure data. More than a thousand data elements can be visualised in TreeMaps. A second example is the work at AT\&T that has focused on visualising network-related and geographically related data (Becker et al. 1995). Other examples include SemNet for visualising knowledge base information using a hierarchical context (Fairchild et al. 1988), and Cone Trees for visualising huge information hierarchies (Carriere and Kazman 1995). Yet another example is the Geographic Information System (GIS), which uses the geographical structures among data objects. In summary, these information visualisation studies, and the visualisation systems that emerged from them, address the high volume of data that is typical in managerial decision-making domains.

\subsection{Role of information presentation in manufacturing}

The challenge to producers - who may or may not be manufacturing a product - is to improve the synchronisation of component parts brought together for the finished product often in the context of the global environment. This coordination and waste elimination strategy is a fundamental principle of lean manufacturing that has broad application in the manufacturing base. Just-In-Time delivery is required for many manufacturing processes to minimise inventory and line-side stock. Where perishable produce is concerned, Just-In-Time delivery is essential if the end product is to reach the consumer in a saleable condition (Wheatley 2004). In this model a key factor is the time taken to move produce from lower tier supplier to the tier one or Original Equipment Manufacturer. In planning this process simple logistics tools tend to imitate traditional master production schedules. Where there are varying customer demand schedules, there is a need to be able to change rapidly to reflect the aggregate Bill of Materials for the period of production in question. The inability of planning aids to reflect this variability is a typical limitation of less sophisticated scheduling applications. Advanced Planning and Scheduling systems are increasingly used to help Manufacturing, Production and Logistics planners satisfy manufacturing constraints; the two principal types relate to external logistics and shop floor planning. Successful application of these tools highlights an important consideration for visualisation based decision support tools - 'how intuitive they are to apply'. Intuitive use includes being able to query (use) the tool using natural language or non-imperative communication and receive information in a language neutral format both of which will aid uptake of this technology.

\subsection{Key functional requirements for manufacturing sequence information presentation}

The key functional requirements for manufacturing sequence information presentation are summarised in Table 2. 
A brief description of these functional requirements is provided below.

- Dynamically Update with Manufacturing Sequence Data: The constant flow of materials throughout the manufacturing process requires quick and easy access to information about a constantly changing environment. The data visualisation system should dynamically update with manufacturing sequence data to satisfy historical and real-time information requirements (Ping 1996, Tien-Lung 2003).

- Maximise Benefits from Just-In-Time Lean Manufacturing by Highlighting Areas Where Problems Consistently Occur: Benefits from Just-In-Time Lean Manufacturing are maximised when delivery of components and assemblies to production is matched by assembly of those components to a finished product in a planned order. The data visualisation system should highlight where production has to invest resources to meet the production schedule and where an un-buildable mix is consistently being given either because of regular plant breakdowns or other constraints (Gerace and Gallimore 2001, Sackett and Williams 2003b).

- Communicate Current and Predicted Production Status: The data visualisation system should process and display manufacturing sequence data to communicate an accurate impression of the production status to the manufacturing personnel. It should show where the manufacturing plant currently stands with respect to derivatives. It should also predict the effect of the volume constraints and the future customer Order Bank (Keim 2002, Sackett and Williams 2003a).

- Address Different Levels of Decision Makers: A typical manufacturing scenario involves multiple decision makers, such as manufacturing management, supervision and operations personnel, requiring different levels of information. Therefore the data visualisation system is required to have the ability of displaying the information in a hierarchical form (Zhang 1998). The major advantage of interactive hierarchical graphs over static images is the ability to drill down to more in-depth information if needed (Yurin 1994).

- Communicate Information with Suppliers: Achieving the right product mix whilst meeting customer demand requires effective communication with the global supplier base. Information should be easily extracted and exchanged between databases, enhancing Advanced Planning and Scheduling applications. The new Internet and collaboration technologies open up further opportunities of making the tool available to suppliers and other external parties (Lee and Campbell 2003). This implies that items requiring a high processing overhead are less likely to be communicated. However, computationally expensive items could have a higher value in the context of visualisation and would consequently be transferred at the expense of 'cheaper' data.

- Deal with Complex \& Disparate Software/Databases in a Manufacturing Environment: The data visualisation system should integrate with legacy, as well as state-of-the-art, off-the-shelf technology - or a combination of the two (Wu and Ellis 2000). Large multi-dimensional, cross-relational databases have become very common for the management and distribution of information throughout manufacturing organisations. Managers as well as front-line workers need tools for the exploration and analysis of these databases (Hameri and Nihtila 1998). These tools should be able to connect directly to multiple data sources. The resulting displays should have the ability to change dynamically as the data underneath them evolves. Here it is important to note that the level of intervention required by the 'technician' implementing such communication will vastly improve the opportunity for uptake of the technology.

\section{5. $\quad$ Functional mapping}

Table 3 identifies the visualisation functionalities that address the key functional requirements for manufacturing sequence information presentation. The offered functions of visualisation are extracted from Table 1 and the key functional requirements for manufacturing sequence information presentation are 


\section{P. J. Sackett et al.}

extracted from Table 2. Table 3 shows that all the functional requirements are serviced by at least one visualisation functionality. As an example, the functional requirement 'highlight areas where problems consistently occur' is addressed by the following visualisation functionalities: 'focus attention', 'trigger memory', 'stimulate thinking', 'challenge self-imposed constraint', 'identify structure, trends, and relationships', and 'highlight key factors'.

Table 3: Visualisation functionalities and functional requirements

Table 4 maps the visualisation techniques (extracted from Figure 2) to the functional requirements (extracted from Table 2). As an example, the functional requirement 'highlight areas where problems consistently occur' is addressed by the following visualisation techniques: filtering, zoom, and distortion. Table 4 illustrates that some functional requirements (such as 'dynamically update with manufacturing sequence data' and 'communicate information with suppliers') are more challenging for the visualisation techniques than other requirements. Similar to the case of Table 3, all the functional requirements are serviced by more than one visualisation technique. Tables 3 and 4 can together be used to identify the visualisation functionalities and techniques that service each of the key functional requirements for manufacturing sequence information presentation.

Table 4: Visualisation techniques and functional requirements

Table 5 maps the data visualisation applications reported in literature to the functional requirements for manufacturing sequence information presentation. Typically these real world applications involve a combination of visualisation techniques. A majority of these applications in literature correspond to four of the functional requirements presented in Table 5:

- Communicate Current and Predicted Production Status: Many data visualisation applications deal with generating plots for analysing a data set or stream for process monitoring, analysis and visualisation.

- Highlight Areas Where Problems Consistently Occur: This is one of the key motivations for the majority of process monitoring and virtual reality related applications of data visualisation.

- Address Different Levels of Decision Makers: This functional requirement is addressed by a wide variety of application areas. Many of these applications provide drill-down operations, while preserving an overview of the data. This functionality allows the users to focus on causality. It also makes the visualisation tool useful for a broad range of users, requiring different levels of information. In addition, it provides a common platform to different levels of decision makers to communicate with each other.

- Deal with Complex and Disparate Software/Databases: There are two main categories of applications that address this functional requirement. The first category of applications deals with the integration of external systems with the visualisation tool. This reduces the user intervention and eases the use of the visualisation tool, thereby improving the opportunity for uptake of the technology. The second category of applications aims to identify patterns to visualise the abstract, multi-dimensional production data stored in tables. The idea here is to take advantage of human's rapid and flexible pattern recognition capacity to provide a powerful information-processing environment. As shown in Table 5, a wide variety of application areas deal with this functional requirement. 
Table 5: Applications and functional requirements

Table 5 highlights that there is a dearth of applications reported in literature for 'dynamically updating with manufacturing sequence data' and 'communication with suppliers', both of which are critical in a global manufacturing environment. This is in-line with the observation from Table 4 that there is a lack of visualisation techniques in these two areas.

\section{Discussion and conclusions}

Tables 3 and 4 demonstrate that all the functional requirements are serviced by at least one visualisation functionality and at least one visualisation technique. Some functional requirements (such as 'dynamically update with manufacturing sequence data' and 'communicate information with suppliers') are more challenging for the visualisation techniques than other requirements. This also explains the dearth of applications reported in literature in these areas, Table 5. However, the fast growing enabling technologies (such as ready availability of processing power and displays, the Internet, interface standards and advanced algorithms) are now providing new opportunities to deal with the challenges posed by these areas.

As shown in Table 5, there are a number of applications reported in literature for communicating current and predicted production status, highlighting areas where problems consistently occur, addressing different levels of decision makers, and dealing with complex and disparate software/databases. In our analysis, we have made no comment concerning the intrinsic or relative effectiveness of the various visualisation techniques. There are two reasons for this. First, the value of a particular technique depends very much upon the application domain, the user and the task being performed. Second, a combination of techniques is typically involved in a real world application.

The above analysis draws out that the same underlying data can contain a variety of information that has value to a number of users. These users can be considered as information 'consumers' on the basis that the information is needed to make decisions that affect business efficiency and ultimately survival. Therefore the same base data needs to be viewed from a number of different perspectives, and hence prescriptive visualisation has relatively limited application.

By extension we can argue that supply chain efficiency/coordination can be improved by providing tools that expose the impact of decisions in one part of the supply chain on overall performance. For the Original Equipment Manufacturers this can be interpreted as the impact on Just-In-Time manufacturing and their ability to produce to schedule. There is another parallel that can be drawn if we take the concept of exposure, as mentioned above, and consider web services. Essentially web services are a set of networking or communication protocols. Simple web services can be thought of as transactional dialogues; complex web services as longer term, more diverse and focused on business process management rather than discrete decision management. Web services are based around a number of Internet standards and exploit properties of discovery and exposure. A new web service could be written to visualise certain data and, for example, supply chain collaborators would then 'discover' this service when it announced or 'exposed' itself.

The graphical representation of data should itself be kept under control and not allowed to become too 'clever' for the user to interpret. The main concern here is in the use of three-dimensional representation. Current display technology is restricted to two dimensions. This constrains the essential spatial component of 3-D display and hence the associated information. Additionally there is the cognitive limitation of the user in 


\section{P. J. Sackett et al.}

being able to assimilate and process the data when represented in this way. To address these issues, there is a need to introduce a significant level of interactivity which itself raises the level of technology that would be required to visualise the data. Where the 3-D representation is particularly useful is in situations where the graphic being used to represent a variable or variables enhances understanding because of an association for example the usage of a computer disk drive through a volumetric analogy - how empty or full is the drive.

There are four main areas of relevant future research and development.

This paper has highlighted that there is a dearth of data visualisation applications reported in literature for 'dynamically updating with manufacturing sequence data' and 'communication with suppliers', both of which are critical in a global manufacturing environment. Exploitation of visualisation techniques to service these two functional requirements for manufacturing sequence information presentation is therefore an important area for future research.

Another research direction involves the exploitation of knowledge capture in manufacturing sequence data visualisation. This can be achieved through the integration with existing manufacturing systems where this compliments the visualisation and allows a cross-section of the process state at a given point in time as an additional diagnostic.

Enhancing the capability of visualisation tools to adjust to a number of different permutations of process states would be helpful. The motivation here is to develop a visualisation tool that is capable of being employed in a variety of situations. In this case, contemporary programming approaches lend themselves to such diversity.

The global nature of manufacturing has potential implications for visualisation in sequence management. The development of data visualisation tools that appreciate culturally embedded communication differences between eastern and western organisations is a prospective area. Although there is information concerning the impact of cultural differences on business in general (Trompenaars and Hampden-Turner 2003) and the embedded cultural messages that need to be considered when cross cultural communication is undertaken, no material has been published concerning the different requirements of these supply chains. Based on the difference in organisation and culture, it would seem reasonable to expect the information broadcast to the two supply bases to vary. However, the global adoption of lean manufacturing principles and common goal of waste reduction will tend to over-ride any significant difference in information requirement arising as a result of cultural difference. Culturally embedded communication differences will therefore continue to be an issue in terms of presentation but it will be of secondary importance to the format in which sequence or scheduling information is presented. The authors conclude that much of the functionality required already resides in the visualisation tools but it is not being exploited.

\section{References}

Abello, J. and Korn, J., MGV: A system for visualizing massive multidigraphs, IEEE Transactions on Visualization and Computer Graphics, 2002, 8(1), pp. 21-38.

Adam, G.K. and Mastorakis, N.E., High level programming and control of a manufacturing system, WSEAS Transactions on Circuits and Systems, 2003, 2(1), pp. 301-308. 
Alabastro, M.S., Beckmann, G., Gifford, G., Massey, A.P. and Wallace, W.A., The use of visual modeling in designing a manufacturing process for advanced composite structures, IEEE Transactions on Engineering Management, 1995, 42(3), pp. 233-242.

Alpern, B. and Carter, L., The hyperbox, in Proceedings of the $2^{\text {nd }}$ IEEE Conference on Visualization, 1991, San Diego, California, pp. 133-139.

Asahi, T., Turo, D. and Shneiderman, B., Using treemaps to visualize the analytic hierarchy process, Information Systems Research, 1995, 6(4), pp. 357-375.

Asimov, D., The grand tour: A tool for viewing multidimensional data, SIAM Journal on Scientific \& Statistical Computing, 1985, 6(1), pp. 128-143.

Baldwin, D.F., Abell, T.E., Lui, M.-C.M., De Fazio, T.L. and Whitney, D.E., An integrated computer aid for generating and evaluating assembly sequences for mechanical products, IEEE Transactions on Robotics and Automation, 1991, 7(1), pp. 78-94.

Bassett, E., Better data analysis? Visualize!, InTech, 1995, 42(9), pp. 82-84.

Becker, R.A., Eick, S.G. and Wilks, A.R., Visualizing network data, IEEE Transactions on Visualization and Computer Graphics, 1995, 1(1), 16-28.

Bier, E.A., Stone, M.C., Pier, K., Buxton, W. and DeRose, T., Tool glass and magic lenses: The see-through interface, in Computer Graphics Proceedings, 1993, pp. 73-80.

Bo, H., Bin, J. and Hui, L., An integration of GIS, virtual reality and the Internet for visualization, analysis and exploration of spatial data, International Journal of Geographical Information Science, 2001, 15(5), pp. 439-456.

Carriere, J. and Kazman, R., Interacting with huge hierarchies: Beyond cone trees, in Proceedings of IEEE InfoVis'95, 1995, Atlanta, pp. 74-81.

Chen, C., Information visualisation and virtual environments, Springer-Verlag, London, 1999.

Chernoff, H., The use of faces to represent points in k-dimensional space graphically, Journal of the American Statistical Association, 1973, 68, pp. 361-368.

Cleveland, W.S., Visualizing data, Hobart Press, New Jersey, 1993.

Cook, D.F., Zobel, C.W. and Nottingham, Q.J., Excel-based application of data visualization techniques for process monitoring in the forest products industry, Forest Products Journal, 2004, 54(5), pp. 57-65.

Cunha, P., Dionisio, J. and Henriques, E., An architecture to support the manufacturing system design and planning, International Journal of Computer Integrated Manufacturing, 2003, 16(7-8), pp. 605-612.

Davies, J. and Mabin, V., Knowledge management and the framing of information: A contribution to OR/MS pedagogy and practice, Journal of Operational Research Society, 2001, 52(8), pp. 856-573.

DeSanctis, G., Computer graphics as decision aids: Directions for research, Decision Sciences, 1984, 15(4), pp. 463-487.

Dodge, M., Web visualization, http://www.geog.ucl.ac.uk/casa/martin/geography_of_cyberspace.html, October 2001.

Duffy, V.G., Yen, B.P.C. and Cross, G.W., Internet marketing and product visualization (IMPV) system: Development and evaluation in support of product data management, International Journal of Computer Integrated Manufacturing, 2004, 17(1), pp. 1-15.

Eden, C., Cognitive mapping, European Journal of Operational Research, 1988, 36, pp. 1-13.

Eden, C. and Ackerman, F., Making strategy: The journey of strategic management, Sage Publications, London, 1998.

Fairchild, K.M., Poltrock, S.E. and Furnas, G.W., SemNet: Three dimensional graphic representations of large knowledge bases, In Cognitive Science and its Applications for Human-Computer Interaction, edited by R. Guindon, pp. 201-233, 1988 (Lawrence Erlbaum Associates: London). 


\section{P. J. Sackett et al.}

Farrell, E.J. and Zappulla, R.A., Three-dimensional data visualization and biomedical applications, CRC Critical Reviews in Biomedical Engineering, 1989, 16(4), pp. 323-363.

Feiner, S. and Beshers, C., Visualizing n-dimensional virtual worlds with n-vision, Computer Graphics, 1990, 24(2), pp. 37-38.

Foil, C.M. and Huff, A.S., Maps for managers: Where are we?, Where do we go from here?, Journal of Management Studies, 1992, 29(3), pp. 267-285.

Freitag, L. and Urness, T., Analyzing industrial furnace efficiency using comparative visualization in a virtual reality environment, ASME Journal of Manufacturing Science and Engineering, 2002, 124(2), pp. 456461.

Gausemeier, J., Ebbesmeyer, P. and Kallmeyer, F., Produktinnovation: Strategische planung und entwicklung der produkte von morgen, Carl Hanser Verlag, Denmark, 2001.

Gazmuri, P. and Arrate, I., Modeling and visualization for a production planning decision support system, International Transactions in Operational Research, 1995, 2(3), pp. 249-258.

Gerace, J. and Gallimore, J.J., Evaluation of visual display techniques for assembly sequence planning, Human Factors and Ergonomics in Manufacturing, 2001, 11(3), pp. 213-231.

Grinstein, G. and Ward M., Introduction to data visualization. In Information Visualization in Data Mining and Knowledge Discovery, edited by U. Fayyad, G. Grinstein and A. Wierse, pp. 21-47, 2002 (Morgan Kaufmann: USA).

Groombridge, P., Oloyede, A. and Doherty-Bigara, P., Development and implementation of visual feedback technology in automotive windscreen manufacture, Journal of Materials Processing Technology, 2003, 139(1-3), pp. 357-361.

Hameri, A.-P. and Nihtila, J., Visualizing the factory through meta-manufacturing processes, Production Planning and Control, 1998, 9(1), pp. 28-35.

Hearst, M., Tilebars: Visualization of term distribution information in full text information access, in Proceedings of the ACM SIGCHI Conference on Human Factors in Computing Systems, 1995, Denver, pp. 55-66.

Hollocks, B.W., Improving manufacturing operations with WITNESS computer simulation, AT\&T Technology, 1991, 6(1), pp. 16-21.

Horn, R.E., Mapping hypertext: Analysis, linkage, and display of knowledge for the next generation of on-line text and graphics, The Lexington Institute, 1989.

$\mathrm{Hu}, \mathrm{D} ., \mathrm{Hu}, \mathrm{Y}$. and Li, C., Mechanical product disassembly sequence and path planning based on knowledge and geometric reasoning, International Journal of Advanced Manufacturing Technology, 2002, 19(9), pp. 688-696.

Huber, P.J., Projection pursuit, The Annals of Statistics, 1985, 13(2), pp. 435-474.

Inselberg, A. and Dimsdale, B., Parallel coordinates: A tool for visualizing multi-dimensional geometry, in Proceedings of the 1st IEEE Conference on Visualization, 1990, San Francisco, pp. 361-378.

Jezernik, A. and Hren, G., A solution to integrate computer-aided design (CAD) and virtual reality (VR) databases in design and manufacturing processes, International Journal of Advanced Manufacturing Technology, 2003, 22(11-12), pp. 768-774.

Johnson, B. and Shneiderman, B., Treemaps: A space-filling approach to the visualization of hierarchical information, in Proceedings of the IEEE Visualization ' 91, 1991, Piscataway, pp. 284-291.

Johnston, J.C. and Thompson, D.A., Visualization and animation in manufacturing and materials, Journal of Operations Management, 1993, 45(10), pp. 14-19.

Jorgensen, A.C., Rantanen, J., Luukkonen, P., Laine, S. and Yliruusi, J., Visualization of a pharmaceutical unit operation: Wet granulation, Analytical Chemistry, 2004, 76(18), pp. 5331-5338. 
Kaplan, R.S. and Norton, D.P., Having trouble with your strategy? Then map it, Harvard Business Review, September-October 2000, pp. 167-176.

Keim, D.A., Designing pixel-oriented visualization techniques: Theory and applications, IEEE Transactions on Visualization and Computer Graphics, 2000, 6(1), pp. 59-78.

Keim, D.A., Information visualization and visual data mining, IEEE Transactions on Visualization and Computer Graphics, 2002, 8(1), pp. 1-8.

Keim, D.A., Visual exploration of large databases, Communications of the ACM, 2001, 44(8), pp. 38-44.

Keim, D.A. and Kriegel, H.-P., VisDB: Database exploration using multidimensional visualization, Computer Graphics \& Applications, 1994, 6, pp. 40-49.

Keim, D.A., Kriegel, H.-P. and Ankerst, M., Recursive pattern: A technique for visualizing very large amounts of data, in Proceedings of Visualization '95, 1995, Atlanta, pp. 279-286.

Kim, W.C. and Mauborgne, R., Charting your company’s future, Harvard Business Review, 2002, 80(6), pp. 77-83.

Larkin, J.H. and Simon, H.A., Why a diagram is (sometimes) worth ten thousand words, Cognitive Science, 1987, 11(1), pp. 65-99.

Latham, R., The dictionary of computer graphics and virtual reality, Springer-Verlag, New York, 1995.

Lau, H.Y.K., Mak, K.L. and Lu, M.T.H., A virtual design platform for interactive product design and visualization, Journal of Materials Processing Technology, 2003, 139(1-3), pp. 402-407.

LeBlanc, J., Ward, M.O. and Wittels, N., Exploring n-dimensional databases, Proceedings of Visualization '90, 1990, Los Alamitos, CA, pp. 230-239.

Lee, H.J., and Campbell, I., Internet-based design visualization for layered manufacturing, Concurrent Engineering: Research and Applications, 2003, 11(2), pp. 151-158.

Levkowitz, H., Color icons: Merging color and texture perception for integrated visualization of multiple parameters, in Proceedings of Visualization '91, 1991, San Diego, pp. 22-25.

Lohse, G., Biolsi, K., Walker, N. and Rueter, H., A classification of visual representations, Communications of the ACM, 1994, 37(12), pp. 36-49.

Lopez, N., Kreuseler, M. and Schumann, H., A scalable framework for information visualization, IEEE Transactions on Visualization and Computer Graphics, 2002, 8(1), pp. 39-51.

Lu, S.C., Rebello, A.B., Miller, R.A., Kinzel, G.L. and Yagel, R., A simple visualization tool to support concurrent engineering design, Computer Aided Design, 1997, 29(10), pp. 727-735.

Mackay, J.M., Barr, S.H. and Kletke, M.G., An empirical investigation of the effects of decision aids on problem solving processes, Decision Sciences, 1992, 23(3), pp. 648-672.

Mackinlay, J.D., Robertson, G.G. and Card, S.K., The perspective wall: Detail and context smoothly integrated, in Proceedings of Human Factors in Computing Systems Conference, 1991, New Orleans, pp. 173-179.

Mckim, R.H., Experiences in visual thinking, Wadsworth Publishing, Belmont, CA, 1972.

Mersinger, M. and Westkämper, E., Virtual reality for supporting the configuration of transformable assembly systems, Journal of Advanced Manufacturing Systems, 2002, 1(1), pp. 107-112.

Mills, J., Neely, A., Platts, K. and Gregory, M., Manufacturing strategy: A pictorial representation, International Journal of Operations \& Production, 1998, 18(11), pp. 1067-1085.

Mintzberg, H. and Van der Heyden, L., Organigraphs: Drawing how companies really work, Harvard Business Review, 1999, 77(5), pp. 87-94.

Morgan, G., Images of organisation, Berrett-Koehler Publishers, San Francisco, CA, 1998.

Morgan, G., Imagination: The art of creative management, Sage Publications, 1993.

Mujber, T.S., Szecsi, T. and Hashmi, M.S.J. , Virtual reality applications in manufacturing process simulation, Journal of Materials Processing Technology, 2004, 155-156(1-3), pp. 1834-1838. 
Munzner, T. and Burchard, P., Visualizing the structure of the world wide web in 3D hyperbolic space, in Proceedings of Virtual Reality Modeling Language (VRML '95) Symposium, 1995, San Diego, CA, pp. 33-38.

Nottingham, Q.J., Cook, D.F. and Zobel, C.W., Visualization of multivariate data with radial plots using SAS, Computers \& Industrial Engineering, 2001, 41(1), pp. 17-35.

Nowell, L., Havre, S., Hetzler, B. and Whitney, P., Themeriver: Visualizing thematic changes in large document collections, IEEE Transactions on Visualization and Computer Graphics, 2002, 8(1), pp. 9-20.

Orady, E.A., Osman, T.A. and Bailo, C.P., Virtual reality software for robotics and manufacturing cell simulation, Computers \& Industrial Engineering, 1997, 33(1-2), pp. 87-90.

Ozan, E., Majid, H. and Sinan, K., Virtual reality in requirement analysis for CIM system development suitable for SMEs, International Journal of Production Research, 2002, 40(15), pp. 3693 - 3708.

Phaal, R., Farrukh, C.J.P. and Probert, D.R., Technology roadmapping - A planning framework for evolution and revolution, Technological Forecasting and Social Change, 2004, 71(1-2), pp. 5-26.

Pickett, R.M. and Grinstein, G.G., Iconographic displays for visualizing multidimensional data, in Proceedings of IEEE Conference on Systems, Man and Cybernetics, Beijing and Shenyang, People's Republic of China, 1988, pp. 514-519.

Ping Z., Visualizing production planning data, IEEE Computer Graphics and Applications, 1996, 16(5), pp. $7-10$.

Platts, K. and Kim, H.T., Strategy visualisation: Knowing, understanding, and formulating, Management Decision, 2004, 42(5), pp. 667-676.

Przechocki, J., Visualizing temperature data to improve surgical warming systems, Sensors, 1998, 15(12), pp. 10-14.

Rao, R. and Card, S.K., The table lens: Merging graphical and symbolic representation in an interactive focus+context visualization for tabular information, in Proceedings of Human Factors in Computing Systems Conference, 1994, Boston, Massachusetts, pp. 318-322.

Richards, C., Getting the picture: Diagram design and the information revolution, Information Design Journal, 2000, 99(2/3), pp. 87-110.

Robertson, G.G., Mackinlay, J.D. and Card, S.K., Cone trees: Animated 3D visualizations of hierarchical information, Proceedings of Human Factors in Computing Systems Conference, New Orleans, 1991, pp. 189-194.

Rohrer, M., Seeing is believing: The importance of visualization in manufacturing simulation, 2000 Winter Simulation Conference Proceedings, 2000, Orlando, pp. 1211 - 1216.

Rohrer, M., Seeing: The importance of visualization in manufacturing simulation, IIE Solutions, 1997, 29(5), pp. 24-26.

Saboo, J.V. and Deisenroth, M.P., Graphical control of manufacturing work cells, Computers \& Industrial Engineering, 1992, 23(1-4), pp. 49-53.

Sackett, P.J. and Williams, D., Data visualization in manufacturing decision making, Journal of Advanced Manufacturing Systems, 2003a, 2(2), pp. 163-185.

Sackett, P.J. and Williams, D., Making a spectacle, Manufacturing Engineer, 2003b, 82(1), pp. 18-21.

Sarkar, M. and Brown, M., Graphical fisheye views, Communications of the ACM, 1994, 37(12), pp. 73-84.

Setchi, R. and Bratanov, D., Three-dimensional simulation of accommodation, Assembly Automation, 1998, 18(4), pp. 291-301.

Shires, D.R., Green, W. and Walsh, S., Designing, controlling, and visualizing composite material manufacturing, Computing in Science \& Engineering, 2002, 4(4), pp. 86-91.

Shneiderman, B., Tree visualization with treemaps: A 2D space-filling approach, ACM Transactions on Graphics, 1992, 11(1), pp. 92-99. 
Skarlo, T., Flexible landscape: A model for explaining operational mix and volume flexibility, Production Planning and Control, 1999, 10(8), pp. 735-744.

Spence, R., Information visualisation, Addison-Wesley, London, 2001.

Spence, R. and Apperley, M., Data base navigation: An office environment for the professional, Behaviour and Information Technology, 1982, 1(1), pp. 43-54.

Spence, R., Tweedie, L., Dawkes, H. and Su, H., Visualization for functional design, in Proceedings of Visualization 1995 Conference, 1995, Los Alamitos, CA, pp. 4-10.

Spoerri, A., Infocrystal: A visual tool for information retrieval, Proceedings of Visualization '93, 1993, San Jose, CA, pp. 150-157.

Srinivas N., Robert H.A. and Ram D.S., Observations from supplementing the traditional design process via Internet-based collaboration tools, International Journal of Computer Integrated Manufacturing, 2001, 14(1), pp. $95-107$.

Sundin, A. and Medbo, L., Computer visualization and participatory ergonomics as methods in workplace design, Human Factors and Ergonomics in Manufacturing, 2003, 13(1), pp. 1-17.

Tan, K.H. and Platts, K., Linking objectives to action plans: A decision support approach based on the connectance concept, Decision Sciences Journal, 2003a, 34(3), pp. 569-593.

Tan, K.H. and Platts, K., Winning decisions: Translating business strategy into action plans, CMIL, University of Cambridge, Cambridge, 2003b.

Tang, D., Stolte, C. and Hanrahan, P., Polaris: A system for query, analysis and visualization of multidimensional relational databases, IEEE Transactions on Visualization and Computer Graphics, 2002, 8(1), pp. 52-65.

Tegarden, D.P., Business information visualisation, Communications of the Association for Information Systems, 1999, 1(4), pp. 1-37.

Thomasma, T., Youyi M. and Ulgen, O.M., A visual programming system for defining behavior in simulation models of manufacturing systems, Annals of Operations Research, 1994, 53, pp. 357-389.

Tien-Lung, S., An icon-based data image construction method for production data visualization, Production Planning \& Control, 2003, 14(3), pp. 290 - 303.

Trompenaars, F. and Hampden-Turner, C., Riding the waves of culture, Nicholas Brealey Publishing, London, 2003.

Tufte, E., Envisioning information, Graphics Press, Cheshire, 1990.

Tufte, E., The visual display of quantitative information, Graphics Press, Cheshire, 1983.

van Wijk, J.J. and van Liere, R.D., Hyperslice, in Proceedings of the Conference on Visualization'93, 1993, San Jose, CA, pp. 119-125.

Vessey, I., Cognitive fit: A theory-based analysis of the graphs versus tables literature, Decision Sciences, 1991, 22(2), pp. 219-240.

Wang, J.-F., Liu, J.-H. and Zhong, Y.-F., Collaborative assembly planning system under Web environment, Computer Integrated Manufacturing Systems, 2004, 10(1), pp. 83-94.

Ward, M.O., Xmdvtool: Integrating multiple methods for visualizing multivariate data, Proceedings of the IEEE Visualization Conference, 1994, Washington, D.C., pp. 326- 336.

Waurzyniak, P., Visualizing the virtual factory, Manufacturing Engineering, 2004, 132(3), pp. 49-56.

Weick, K.E., The social psychology of organizing, McGraw Hill, New York, 1979.

Wen-Tsai, S. and Shih-Ching, O., Using virtual reality technologies for manufacturing applications, International Journal of Computer Applications in Technology, 2003, 17(4), pp. 213-219.

Wheatley, M., Salads on schedule, The Manufacturer, 2004, 7(9), pp. 55-59.

Wiendahl, H.-P. and Fiebig, T.H., Virtual factory design: A new tool for a co-operative planning approach, International Journal of Computer Integrated Manufacturing, 2003, 16(7-8), pp. 535 - 540. 


\section{P. J. Sackett et al.}

Wise, J.A., Thomas, J.J., Pennock, K., Lantrip, D., Pottier, M., Schur, A. and Crow, V., Visualizing the nonvisual: Spatial analysis and interaction with information from text documents, Proceedings of the Symposium on Information Visualization, 1995, pp. 51-58.

Wu, B. and Ellis, R., Manufacturing strategy analysis and manufacturing information system design: Process and application, International Journal of Production Economics, 2000, 65, pp. 55-72.

Xiang, W., Chuen, C.W., Wong, C.M. and Yam, L.H., A generative feature-based CAPP/CNC system for hydraulic manifold blocks, International Journal of Advanced Manufacturing Technology, 2002, 19(11), pp. 805-811.

Yafang, S. and Yongwei, S., Visualizing upwelling at Monterey bay in an integrated environment of GIS and scientific visualization, Marine Geodesy, 1999, 22(2), pp. 93 - 103.

Yao, A.W.-L., Kao, S.A. and Li, D.Y., Integrated 3R and VR technologies for creative design and marketing, Journal of Advanced Manufacturing Systems, 2002, 1(2), pp. 189-199.

Yurin, K.E., Interactive graphic subsystem for management and status visualization data network, Avtometriya, 1994, 2, pp. 105-108.

Zha, X.F., Lim, S.Y.E. and Fok, S.C., Integrated knowledge-based assembly sequence planning, International Journal of Advanced Manufacturing Technology, 1998, 14(1), pp. 50-64.

Zhang, P. and Whinston, A.B., Business information visualisation for decision-making support: A research strategy, in First Americas Conference on Information Systems, 1995, Pittsburgh, Pennsylvania, 25-27 August.

Zhang, P., Image construction method for visualizing managerial data, Decision Support Systems, 1998, 23(4), pp. 371-387. 
Table 1: Visualisation functionalities (adapted from Platts and Kim (2004))

\begin{tabular}{|c|c|c|c|}
\hline $\begin{array}{l}\text { Problem } \\
\text { Solving }\end{array}$ & \multicolumn{2}{|c|}{ Offered Functionalities } & Authors \\
\hline \multirow{4}{*}{ 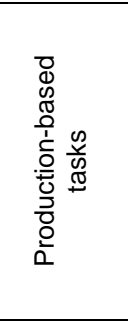 } & Focus attention & $\begin{array}{l}\text { Allows managers to identify the areas of } \\
\text { interest }\end{array}$ & $\begin{array}{l}\text { DeScanctis (1984), Vessey (1991), } \\
\text { Foil and Huff (1992), Mackay et al. } \\
\text { (1992) }\end{array}$ \\
\hline & Trigger memory & $\begin{array}{l}\text { Allows managers to make connections } \\
\text { among past events }\end{array}$ & Tan and Platts (2003a) \\
\hline & Share thinking & $\begin{array}{l}\text { Enables managers to share their } \\
\text { thinking with colleagues }\end{array}$ & Eden (1988), Foil and Huff (1992) \\
\hline & Stimulate thinking & $\begin{array}{l}\text { Provides an invitation to view a situation } \\
\text { in a way that often stimulates fresh } \\
\text { thinking }\end{array}$ & $\begin{array}{l}\text { Tufte (1990), Kim and Mauborgne } \\
\text { (2002) }\end{array}$ \\
\hline \multirow{3}{*}{ 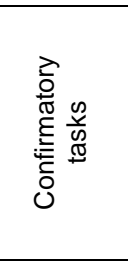 } & $\begin{array}{l}\text { Bridge missing } \\
\text { Information }\end{array}$ & $\begin{array}{l}\text { Exploits the human visual system to } \\
\text { extract information from incomplete data }\end{array}$ & Tegarden (1999) \\
\hline & $\begin{array}{l}\text { Challenge self-imposed } \\
\text { constraint }\end{array}$ & $\begin{array}{l}\text { Enables managers to look at a problem } \\
\text { in a new way }\end{array}$ & $\begin{array}{l}\text { Morgan (1998), Mintzberg and Van } \\
\text { Der Heyden (1999), Davies and } \\
\text { Mabin (2001), Tan and Platts (2003b) }\end{array}$ \\
\hline & Highlight key factors & $\begin{array}{l}\text { Allows managers to specify explicitly } \\
\text { their views on the importance weighting } \\
\text { of variables }\end{array}$ & $\begin{array}{l}\text { Tufte (1983), Eden (1988), Tan and } \\
\text { Platts (2003a) }\end{array}$ \\
\hline \multirow{3}{*}{ 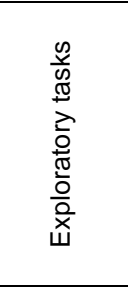 } & $\begin{array}{l}\text { Identifies structure, } \\
\text { trends and relationships }\end{array}$ & $\begin{array}{l}\text { Identifies structure, patterns, trends, } \\
\text { anomalies, and relationships in data }\end{array}$ & $\begin{array}{l}\text { Weick (1979), Zhang and Whinston } \\
\text { (1995), Chen (1999), Mintzberg and } \\
\text { Van Der Heyden (1999), Kaplan and } \\
\text { Norton (2000), Phaal et al. (2004) }\end{array}$ \\
\hline & $\begin{array}{l}\text { Display multivariate } \\
\text { Performance }\end{array}$ & $\begin{array}{l}\text { Enables managers to analyse complex } \\
\text { performance }\end{array}$ & $\begin{array}{l}\text { Mills et al. (1998), Richards (2000), } \\
\text { Kim and Mauborgne (2002) }\end{array}$ \\
\hline & $\begin{array}{l}\text { Provide an overview of } \\
\text { complex data sets }\end{array}$ & $\begin{array}{l}\text { Provides a picture of the problem that is } \\
\text { relatively easily examined, explored, and } \\
\text { changed. }\end{array}$ & $\begin{array}{l}\text { Horn (1988), Tufte (1990), Spence } \\
\text { (2001) }\end{array}$ \\
\hline
\end{tabular}

Table 2: Manufacturing sequence information presentation requirements

\begin{tabular}{|c|c|}
\hline Functional Requirements & $\begin{array}{r}\text { Description } \\
\end{array}$ \\
\hline $\begin{array}{l}\text { Dynamically update with } \\
\text { manufacturing sequence data }\end{array}$ & $\begin{array}{l}\text { - } \quad \text { Manufacturing represents a constantly changing environment } \\
\text { Dynamic update with manufacturing sequence data is required to satisfy } \\
\text { historical and real-time information requirements }\end{array}$ \\
\hline $\begin{array}{l}\text { Maximise benefits from just-in- } \\
\text { time lean manufacturing by } \\
\text { highlighting areas where } \\
\text { problems consistently occur }\end{array}$ & $\begin{array}{l}\text { Benefits from Just-In-Time Lean Manufacturing are maximised when delivery } \\
\text { of components and assemblies to production is matched by assembly of } \\
\text { those components to a finished product in a planned order } \\
\text { Highlight where production has to invest resources to meet the production } \\
\text { schedule } \\
\text { Highlight where an un-buildable mix is consistently being given either } \\
\text { because of regular plant breakdowns or other constraints }\end{array}$ \\
\hline $\begin{array}{l}\text { Communicate current and } \\
\text { predicted production status }\end{array}$ & $\begin{array}{l}\text { - } \\
\text { accurate impression of the production status to the manufacturing personnel } \\
\text { - Show where the manufacturing plant currently stands with respect to } \\
\text { derivatives } \\
\text { - } \quad \text { Predict effect of the volume constraints and the future customer Order Bank }\end{array}$ \\
\hline $\begin{array}{l}\text { Address different levels of } \\
\text { decision makers }\end{array}$ & $\begin{array}{l}\text { - Present multiple levels of details to meet the information requirements of } \\
\text { manufacturing management, supervision and operations personnel } \\
\text { Use interactive hierarchical graphs with the ability to drill down to more in- } \\
\text { depth information if needed }\end{array}$ \\
\hline $\begin{array}{l}\text { Communicate information with } \\
\text { suppliers }\end{array}$ & $\begin{array}{l}\text { - Achieving the right product mix whilst meeting customer demand requires } \\
\text { effective communication with the suppliers } \\
\text { - Use Internet and collaboration technologies to involve suppliers and other } \\
\text { external parties } \\
\text { - Requirement of data transfer over the Web implies that there is a limit on } \\
\text { what can be effectively communicated }\end{array}$ \\
\hline $\begin{array}{l}\text { Deal with complex and disparate } \\
\text { software/databases in a } \\
\text { manufacturing environment }\end{array}$ & $\begin{array}{ll}\text { - } & \text { Integrate with legacy, as well as state-of-the-art, off-the-shelf technology } \\
\text { - } & \text { Dealing with large multi-dimensional, cross-relational databases } \\
\text { - } & \text { Connect directly to multiple data sources } \\
\end{array}$ \\
\hline
\end{tabular}




\section{P. J. Sackett et al.}

Table 3: Visualisation functionalities and functional requirements

\begin{tabular}{|c|c|c|c|c|c|c|c|}
\hline & \multicolumn{6}{|c|}{ Functional Requirements } \\
\hline & & $\begin{array}{l}\text { Dynamically } \\
\text { update with } \\
\text { manufacturing } \\
\text { sequence data }\end{array}$ & $\begin{array}{l}\text { Highlight } \\
\text { areas where } \\
\text { problems } \\
\text { consistently } \\
\text { occur }\end{array}$ & $\begin{array}{l}\text { Communicate } \\
\text { current and } \\
\text { predicted } \\
\text { production } \\
\text { status }\end{array}$ & $\begin{array}{l}\text { Address } \\
\text { different } \\
\text { levels of } \\
\text { decision } \\
\text { makers }\end{array}$ & $\begin{array}{l}\text { Communicate } \\
\text { information } \\
\text { with suppliers }\end{array}$ & $\begin{array}{l}\text { Deal with } \\
\text { complex and } \\
\text { disparate } \\
\text { software/ } \\
\text { databases }\end{array}$ \\
\hline \multirow{10}{*}{ 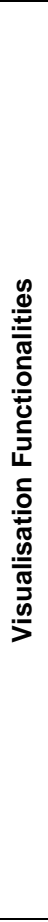 } & $\begin{array}{l}\text { Focus attention (DeSanctis 1984, } \\
\text { Vessey 1991, Foil and Huff 1992, } \\
\text { Mackay et al. 1992) }\end{array}$ & & $x$ & $\mathrm{X}$ & $x$ & $x$ & \\
\hline & $\begin{array}{l}\text { Trigger memory (Tan and Platts, } \\
\text { 2003a) }\end{array}$ & $x$ & $\mathrm{x}$ & $\mathrm{x}$ & & & \\
\hline & $\begin{array}{l}\text { Share thinking (Eden 1988, Foil and } \\
\text { Huff 1992) }\end{array}$ & & & & $x$ & $x$ & $x$ \\
\hline & $\begin{array}{l}\text { Stimulate thinking (Tufte 1990, Kim } \\
\text { and Mauborgne 2002) }\end{array}$ & & $x$ & $\mathrm{X}$ & & & \\
\hline & $\begin{array}{l}\text { Bridge missing information } \\
\text { (Tegarden 1999) }\end{array}$ & $x$ & & $\mathrm{x}$ & & & $x$ \\
\hline & $\begin{array}{l}\text { Challenge self-imposed constraint } \\
\text { (Morgan 1998, Mintzberg and Van } \\
\text { der Heyden 1999, Davies and } \\
\text { Mabin 2001, Tan and Platts, 2003b) }\end{array}$ & & $x$ & & $x$ & $x$ & \\
\hline & $\begin{array}{l}\text { Identify structure, trends and } \\
\text { relationships (Weick 1979, Zhang } \\
\text { and Whinston 1995, Chen 1999, } \\
\text { Mintzberg and Van der Hayden } \\
1999, \text { Kaplan and Norton 2000, } \\
\text { Phaal et al. 2004) }\end{array}$ & $x$ & $x$ & $x$ & $x$ & $x$ & $x$ \\
\hline & $\begin{array}{l}\text { Display multivariate performance } \\
\text { (Mills et al. 1998, Richards 2000, } \\
\text { Kim and Mauborgne 2002) }\end{array}$ & & & $x$ & & & $x$ \\
\hline & $\begin{array}{l}\text { Highlight key factors (Tufte } 1983, \\
\text { Eden 1988, Tan and Platts 2003a) }\end{array}$ & & $x$ & & & & \\
\hline & $\begin{array}{l}\text { Provide an overview of complex } \\
\text { data sets (Horn 1989, Tufte } 1990, \\
\text { Spence 2001) }\end{array}$ & & & $x$ & & & $x$ \\
\hline
\end{tabular}

Table 4: Visualisation techniques and functional requirements

\begin{tabular}{|c|c|c|c|c|c|c|c|}
\hline & & \multicolumn{6}{|c|}{ Functional Requirements } \\
\hline & & $\begin{array}{l}\text { Dynamically } \\
\text { update with } \\
\text { manufacturing } \\
\text { sequence data }\end{array}$ & $\begin{array}{l}\text { Highlight } \\
\text { areas where } \\
\text { problems } \\
\text { consistently } \\
\text { occur }\end{array}$ & $\begin{array}{l}\text { Communicate } \\
\text { current and } \\
\text { predicted } \\
\text { production } \\
\text { status }\end{array}$ & $\begin{array}{l}\text { Address } \\
\text { different } \\
\text { levels of } \\
\text { decision } \\
\text { makers }\end{array}$ & $\begin{array}{l}\text { Communicate } \\
\text { information } \\
\text { with suppliers }\end{array}$ & $\begin{array}{l}\text { Deal with } \\
\text { complex and } \\
\text { disparate } \\
\text { software/ } \\
\text { databases }\end{array}$ \\
\hline \multirow{5}{*}{ 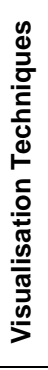 } & Projection (Asimov, 1985) & $x$ & & $\mathrm{X}$ & $\mathrm{X}$ & & $\mathrm{X}$ \\
\hline & $\begin{array}{l}\text { Filtering (Spoerri 1993, Becker } \\
\text { et al. 1995, Tang et al. 2002) }\end{array}$ & & $\mathrm{X}$ & $\mathrm{X}$ & $\mathrm{X}$ & $\mathrm{X}$ & $\mathrm{X}$ \\
\hline & Zoom (Rao and Card, 1994) & & $X$ & $\mathrm{X}$ & $\mathrm{X}$ & & \\
\hline & $\begin{array}{l}\text { Distortion (Spence and Apperley } \\
\text { 1982, Alpern and Carter, } \\
\text { 1991,Mackinlay et al. 1991, } \\
\text { Sarkar and Brown 1994, } \\
\text { Munzner and Burchard 1995) }\end{array}$ & & $\mathrm{X}$ & $\mathrm{X}$ & $\mathrm{x}$ & & $\mathrm{x}$ \\
\hline & $\begin{array}{l}\text { Link \& brush (Lopez et al. } 2002 \text {, } \\
\text { Tang et al. 2002) }\end{array}$ & $\mathrm{X}$ & & & & $\mathrm{X}$ & $\mathrm{X}$ \\
\hline
\end{tabular}


Table 5: Applications and functional requirements

\begin{tabular}{|c|c|c|c|c|c|c|c|}
\hline & \multicolumn{6}{|c|}{ Functional Requirements } \\
\hline & & $\begin{array}{l}\text { Dynamically } \\
\text { update with } \\
\text { manufacturing } \\
\text { sequence data }\end{array}$ & $\begin{array}{l}\text { Highlight areas } \\
\text { where problems } \\
\text { consistently occur }\end{array}$ & $\begin{array}{l}\text { Communicate } \\
\text { current and } \\
\text { predicted production } \\
\text { status }\end{array}$ & $\begin{array}{l}\text { Address different } \\
\text { levels of decision } \\
\text { makers }\end{array}$ & $\begin{array}{l}\text { Communicate } \\
\text { information } \\
\text { with suppliers }\end{array}$ & $\begin{array}{l}\text { Deal with complex and } \\
\text { disparate software/ } \\
\text { databases }\end{array}$ \\
\hline \multirow{5}{*}{ 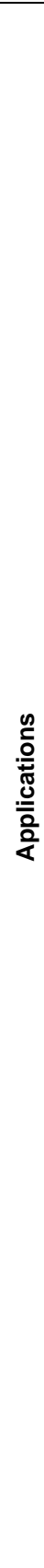 } & 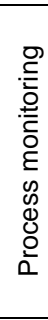 & $\begin{array}{l}\text { (Sackett and } \\
\text { Williams } \\
\text { 2003a) }\end{array}$ & $\begin{array}{l}\text { (Farrell and Zappulla } \\
\text { 1989, Gazmuri and } \\
\text { Arrate 1995, } \\
\text { Przechocki 1998, } \\
\text { Hameri and Nihtila } \\
\text { 1998, Nottingham et } \\
\text { al. 2001, Sackett } \\
\text { and Williams 2003a, } \\
\text { Tien-Lung 2003, } \\
\text { Cook et al. 2004) }\end{array}$ & $\begin{array}{l}\text { (Farrell and Zappulla } \\
\text { 1989, Bassett 1995, } \\
\text { Hameri and Nihtila } \\
\text { 1998, Przechocki } \\
\text { 1998, Skarlo 1999, } \\
\text { Sackett and Williams } \\
\text { 2003a, Tien-Lung } \\
\text { 2003, Cook et al. } \\
\text { 2004, Jorgensen et } \\
\text { al. 2004) }\end{array}$ & $\begin{array}{l}\text { (Farrell and Zappulla } \\
\text { 1989, Gazmuri and } \\
\text { Arrate 1995, Hameri } \\
\text { and Nihtila 1998, } \\
\text { Przechocki 1998, } \\
\text { Skarlo 1999, Yafang } \\
\text { and Yongwei 1999, } \\
\text { Nottingham et al. } \\
\text { 2001, Sackett and } \\
\text { Williams 2003a) }\end{array}$ & & $\begin{array}{l}\text { (Farrell and Zappulla } \\
\text { 1989, Bassett 1995, } \\
\text { Yafang and Yongwei } \\
\text { 1999, Richards 2000, } \\
\text { Sackett and Williams } \\
\text { 2003a, Tien-Lung 2003) }\end{array}$ \\
\hline & 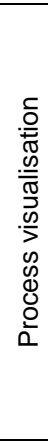 & & $\begin{array}{l}\text { (Baldwin et al. 1991, } \\
\text { Zha et al. 1998, Hu } \\
\text { et al. 2002, } \\
\text { Groombridge et al. } \\
\text { 2003) }\end{array}$ & $\begin{array}{l}\text { (Baldwin et al. 1991, } \\
\text { Lu et al. 1997, Hu et } \\
\text { al. 2002, } \\
\text { Groombridge et al. } \\
\text { 2003, Sundin and } \\
\text { Medbo 2003) }\end{array}$ & $\begin{array}{l}\text { (Baldwin et al. 1991, } \\
\text { Saboo and Deisenroth } \\
\text { 1992, Alabastro et al. } \\
\text { 1995, Ping 1996, Lu et } \\
\text { al. 1997, Zha et al. } \\
\text { 1998, Gerace and } \\
\text { Gallimore 2001, Hu et } \\
\text { al. 2002, Shires et al. } \\
\text { 2002, Groombridge et } \\
\text { al. 2003, Lau et al. } \\
\text { 2003, Sackett and } \\
\text { Williams 2003b, } \\
\text { Sundin and Medbo } \\
\text { 2003) }\end{array}$ & (Ping 1996) & $\begin{array}{l}\text { (Baldwin et al. 1991, } \\
\text { Saboo and Deisenroth } \\
\text { 1992, Alabastro et al. } \\
\text { 1995, Zha et al. 1998, } \\
\text { Gerace and Gallimore } \\
\text { 2001, Shires et al. 2002, } \\
\text { Lau et al. 2003, Sackett } \\
\text { and Williams 2003b) }\end{array}$ \\
\hline & 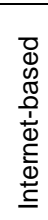 & & $\begin{array}{l}\text { (Bo et al. 2001, } \\
\text { Srinivas et al. 2001) }\end{array}$ & $\begin{array}{l}\text { (Bo et al. 2001, } \\
\text { Srinivas et al. 2001, } \\
\text { Wang et al. 2004) }\end{array}$ & $\begin{array}{l}\text { (Bo et al. 2001, } \\
\text { Srinivas et al. 2001, } \\
\text { Lee and Campbell } \\
\text { 2003, Duffy et al. } \\
\text { 2004, Wang et al. } \\
\text { 2004) }\end{array}$ & $\begin{array}{l}\text { (Lee and } \\
\text { Campbell } \\
\text { 2003, Duffy et } \\
\text { al. 2004) }\end{array}$ & $\begin{array}{l}\text { (Bo et al. 2001, Srinivas } \\
\text { et al. 2001, Lee and } \\
\text { Campbell 2003, Duffy et } \\
\text { al. 2004, Wang et al. } \\
\text { 2004) }\end{array}$ \\
\hline & 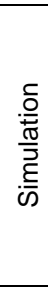 & & $\begin{array}{l}\text { (Orady et al. 1997, } \\
\text { Rohrer 1997, Wen- } \\
\text { Tsai and Shih-Ching } \\
\text { 2003, Waurzyniak } \\
\text { 2004) }\end{array}$ & $\begin{array}{l}\text { (Thomasma et al. } \\
1994, \text { Rohrer } 1997, \\
\text { Wen-Tsai and Shih- } \\
\text { Ching 2003, } \\
\text { Waurzyniak 2004) }\end{array}$ & $\begin{array}{l}\text { (Hollocks 1991, } \\
\text { Thomasma et al. } \\
\text { 1994, Orady et al. } \\
\text { 1997, Rohrer 1997, } \\
\text { Setchi and Bratanov } \\
\text { 1998, Xiang et al. } \\
\text { 2002, Wen-Tsai and } \\
\text { Shih-Ching 2003, } \\
\text { Waurzyniak 2004) }\end{array}$ & & $\begin{array}{l}\text { (Hollocks 1991, } \\
\text { Thomasma et al. 1994, } \\
\text { Orady et al. 1997, } \\
\text { Setchi and Bratanov } \\
\text { 1998, Xiang et al. 2002, } \\
\text { Adam and Mastorakis } \\
\text { 2003, Wen-Tsai and } \\
\text { Shih-Ching 2003, } \\
\text { Waurzyniak 2004) }\end{array}$ \\
\hline & 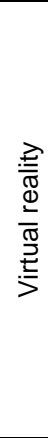 & & $\begin{array}{l}\text { (Orady et al. 1997, } \\
\text { Yao et al. 2002, } \\
\text { Ozan et al. 2002 } \\
\text { Freitag and Urness } \\
\text { 2002, Jezernik and } \\
\text { Hren 2003) }\end{array}$ & $\begin{array}{l}\text { (Ozan et al. 2002, } \\
\text { Wen-Tsai and Shih- } \\
\text { Ching 2003) }\end{array}$ & $\begin{array}{l}\text { (Chernoff 1973, } \\
\text { Johnston and } \\
\text { Thompson 1993, } \\
\text { Orady et al. 1997, Yao } \\
\text { et al. 2002, Mersinger } \\
\text { and Westkämper } \\
\text { 2002, Freitag and } \\
\text { Urness 2002, Ozan et } \\
\text { al. 2002, Wen-Tsai } \\
\text { and Shih-Ching 2003, } \\
\text { Cunha et al. 2003, } \\
\text { Wiendahl and Fiebig } \\
\text { 2003, Mujber et al. } \\
\text { 2004) }\end{array}$ & & $\begin{array}{l}\text { (Johnston and } \\
\text { Thompson 1993, Orady } \\
\text { et al. 1997, Rohrer } \\
\text { 1997, Yao et al. 2002, } \\
\text { Freitag and Urness } \\
\text { 2002, Mersinger and } \\
\text { Westkämper 2002, } \\
\text { Ozan et al. 2002, Wen- } \\
\text { Tsai and Shih-Ching } \\
\text { 2003, Cunha et al. 2003, } \\
\text { Wiendahl and Fiebig } \\
\text { 2003, Jezernik and Hren } \\
\text { 2003, Mujber et al. } \\
\text { 2004) }\end{array}$ \\
\hline
\end{tabular}




\section{P. J. Sackett et al}

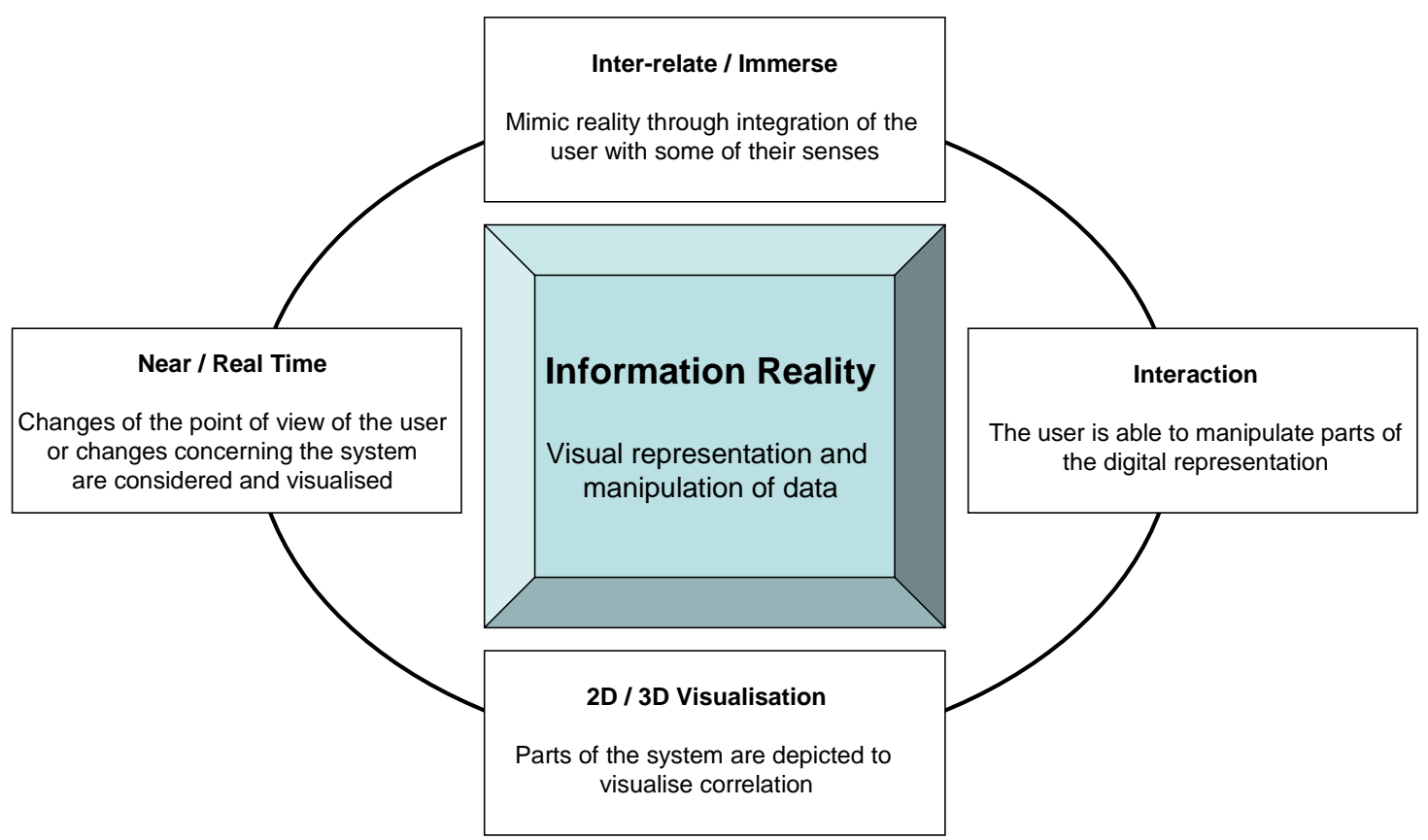

Figure 1: Features of information reality (adapted from Wiendahl and Fiebig (2003))

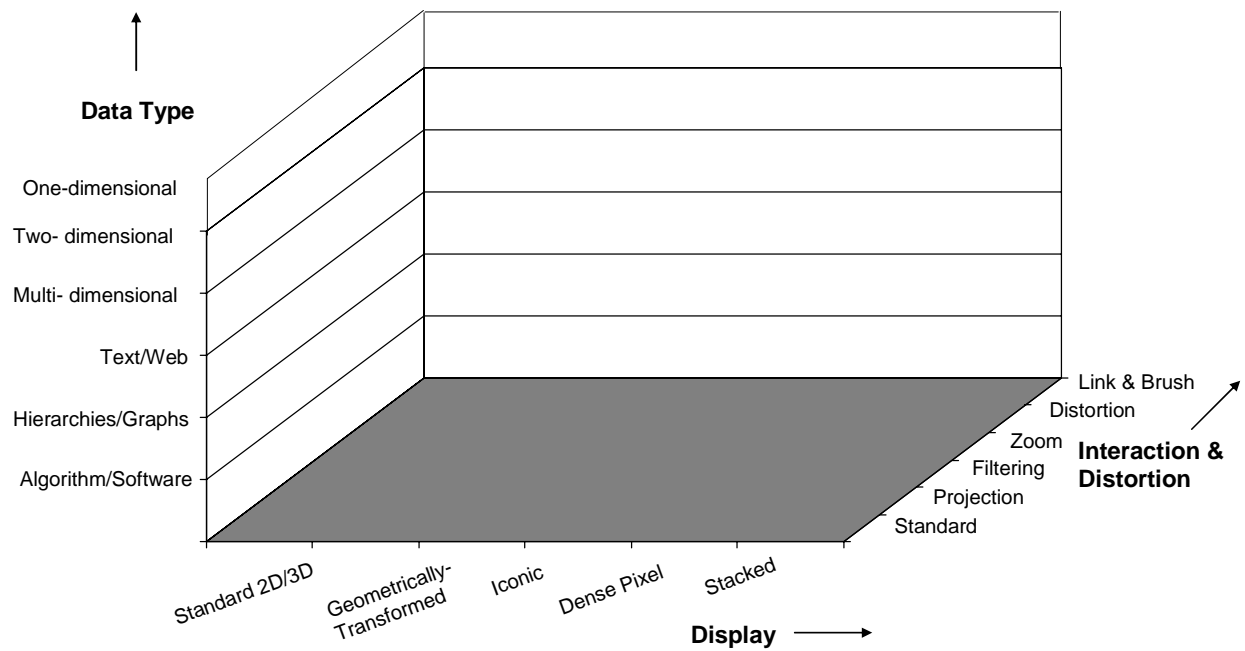

Figure 2: Classification of information visualisation techniques (adapted from Keim (2001)) 


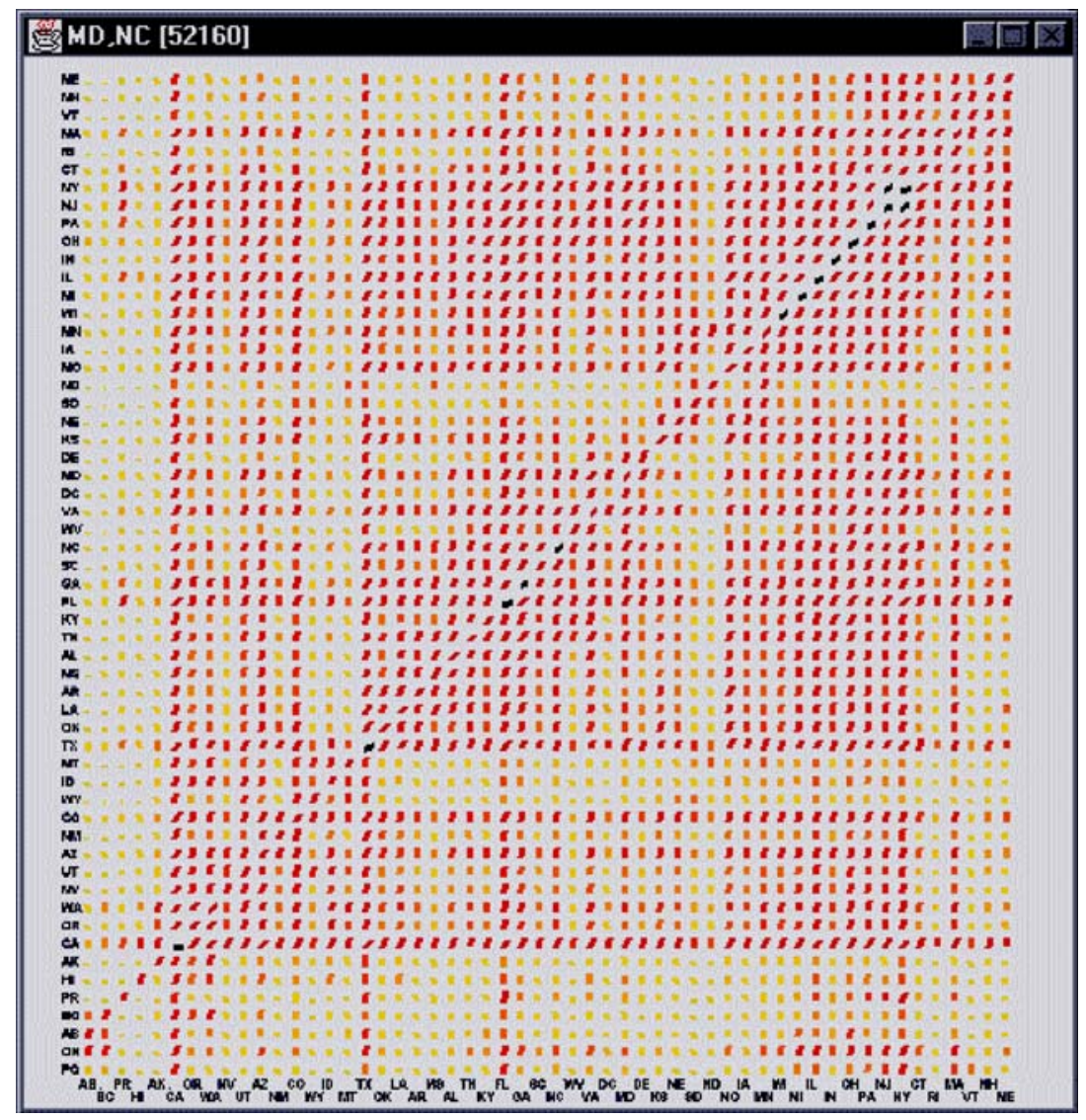

Figure 3: A needle grid view of call data. Each axis represents the states of the US and density of phone calls made between pairs of states is represented with a needle with multiple visual cues: colour, angle, and length (source reference: Abello and Korn (2002))

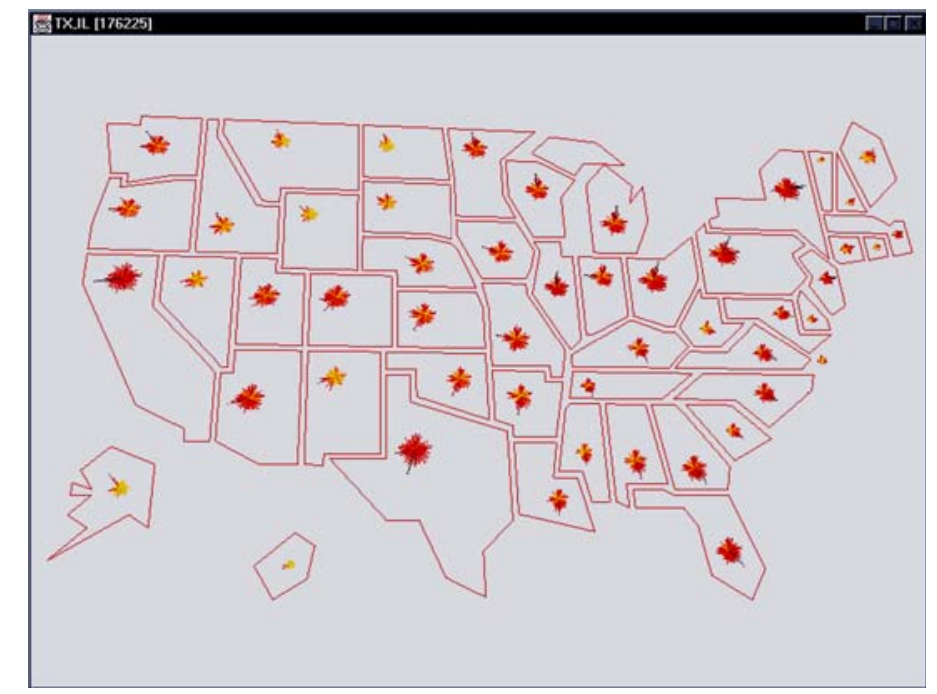

Figure 4: A star-map view of call data, superimposed with geographic information. For each state, a star is drawn which consists of line segments that represent phone call density to each other state. The circular order of the states is the same for all stars (source reference: Abello and Korn (2002)) 
P. J. Sackett et al.
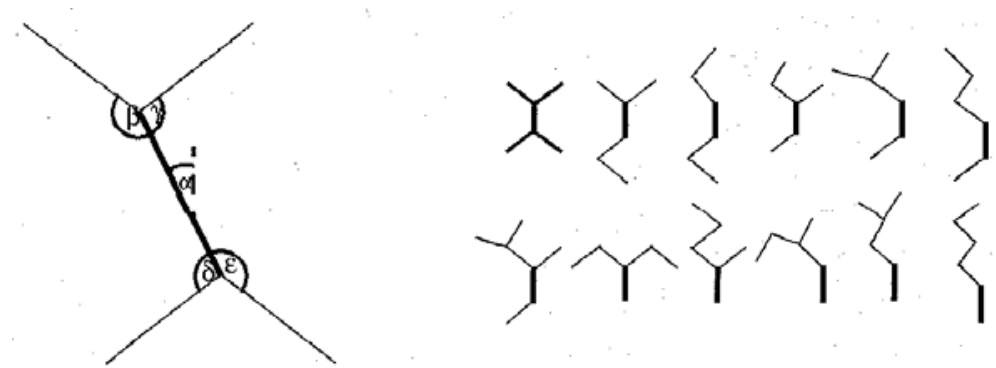

Figure 5: Stick figure visualisation technique: (a) Stick figure icon, (b) A family of stick figures (source reference: Keim and Kriegel (1994))

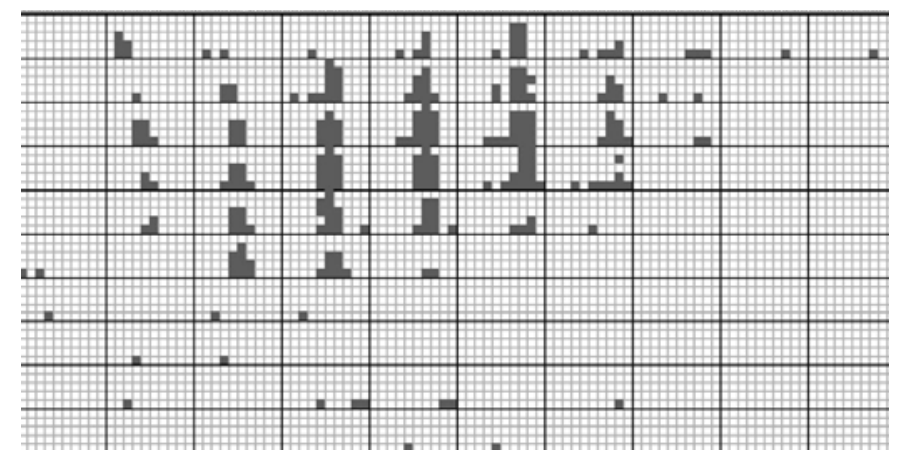

Figure 6: Dimensional stacking visualisation of oil mining data (source reference: Keim (2002)) 